\title{
DETERMINATION OF CAUSES OF SERIES ER2T ELECTRIC MULTIPLE UNIT TRAIN TRACTION GEAR RUBBER-CORD SHELL DAMAGE
}

\author{
Pavels Gavrilovs, Janis Eiduks, Dmitrijs Gorbachovs \\ Riga Technical University, Latvia \\ pavels.gavrilovs@rtu.lv, janis.eiduks_2@rtu.lv,dmitrijs.gorbacovs@rtu.lv
}

\begin{abstract}
The theme of the article was chosen due to a large number of failures of the rubber-cord coupling for traction drive of ER2T series electric multiple unit (EMU) trains. The number of failures was summarized on the basis of the railway company JSC "Pasažieru vilciens", operating on the Latvian railway, reports on unscheduled repairs for the period from 2015 till 2020. In the presented article we will discuss the determination of the reasons for ER2T series EMU trains rubber-cord coupling failure. The object under study was a rubber-cord coupling, which was out of order and taken after unscheduled repair from a motor car No. 2207-02. Based on the results of the test trial on 23.07.2020, the heating temperature of eight rubber-cord couplings was determined on four carriages of the ER2T series train No. 7115R on the route Riga-Jelgava. The shear stress $\tau_{\mathrm{s}}$ and the radial load $\mathrm{F}_{\mathrm{r}}$ acting on the coupling during movement are determined. In the RTU laboratory, the geometric dimensions of the coupling have been determined, the influence of the lubricant action and the temperature effect on the mechanical properties of rubber have been investigated. Based on the research results, the reasons for the failure of the traction drive rubber-cord coupling were analyzed and conclusions were drawn about its possible failure. The research results are compared with standard requirements.
\end{abstract}

Keywords: EMU train, traction gear, rubber-cord coupling, failures.

\section{Introduction}

The rubber-cord coupling [1] is used to transmit the torque from the traction motor to the wheelset gearbox and is attached to the flanges mounted on the traction motor on one side and the small gear shaft of the traction gearbox on the other side. During the movement of the EMU train [2], the rubbercord coupling of the traction drive is subject to various dynamic loads associated with the speed and mode of movement (traction, coasting, braking), as a result of which the rubber-cord coupling may fail. The intensity of the action of these loads in the conditions of suburban traffic is very high, since the mode is being implemented all the time:

- acceleration up to the necessary speed on the section;

- coasting;

- braking to a full stop.

Depending on the occupancy of the car, the rubber-cord coupling of the traction drive may undergo significant misalignment of the shafts, moreover, in the conditions of Latvia, it operates in the temperature range from $-20{ }^{\circ} \mathrm{C}$ to $+30^{\circ} \mathrm{C}$ and is exposed to the gear lubricant as a result of its ejection. As a result of these factors, the properties of rubber can deteriorate and significant stresses can arise in the material of the rubber-cord coupling, resulting to the coupling fail.

At the company JSC "Pasažieru vilciens" operating on the Latvian Railway, the second most important reason for unscheduled repairs of ER2T series EMU train motor car traction gears is the failure of the rubber-cord coupling shell, Fig. 1.

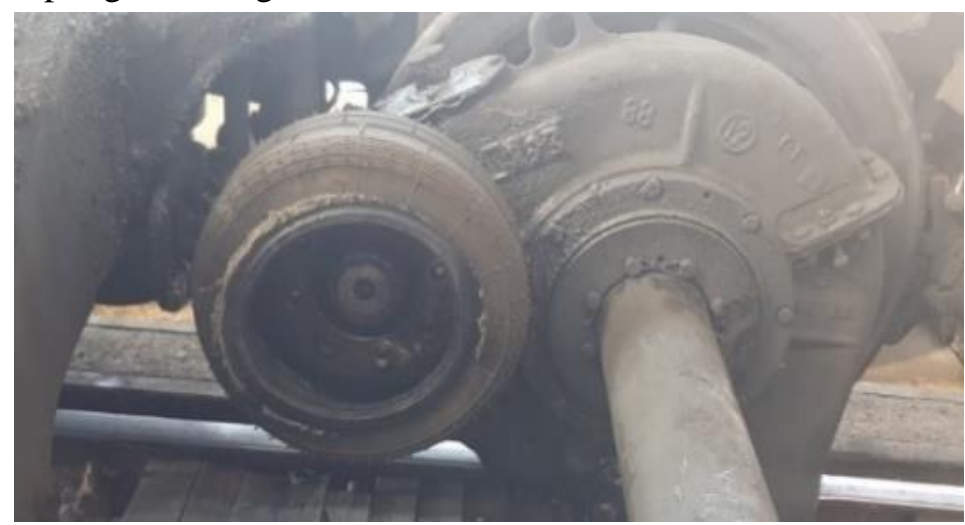

Fig. 1. ER2T car rubber-cord coupling side surface damage 
According to the data presented in the JSC "Pasažieru vilciens" reports on unscheduled repairs, during the period from 2015 till 2020, there were 128 cases of unscheduled repairs of ER2T series motor due to traction drive failures, of which 28 cases were damage to the rubber-cord couplings casing [3]. The analysis of the statistical data is shown in Fig. 2.

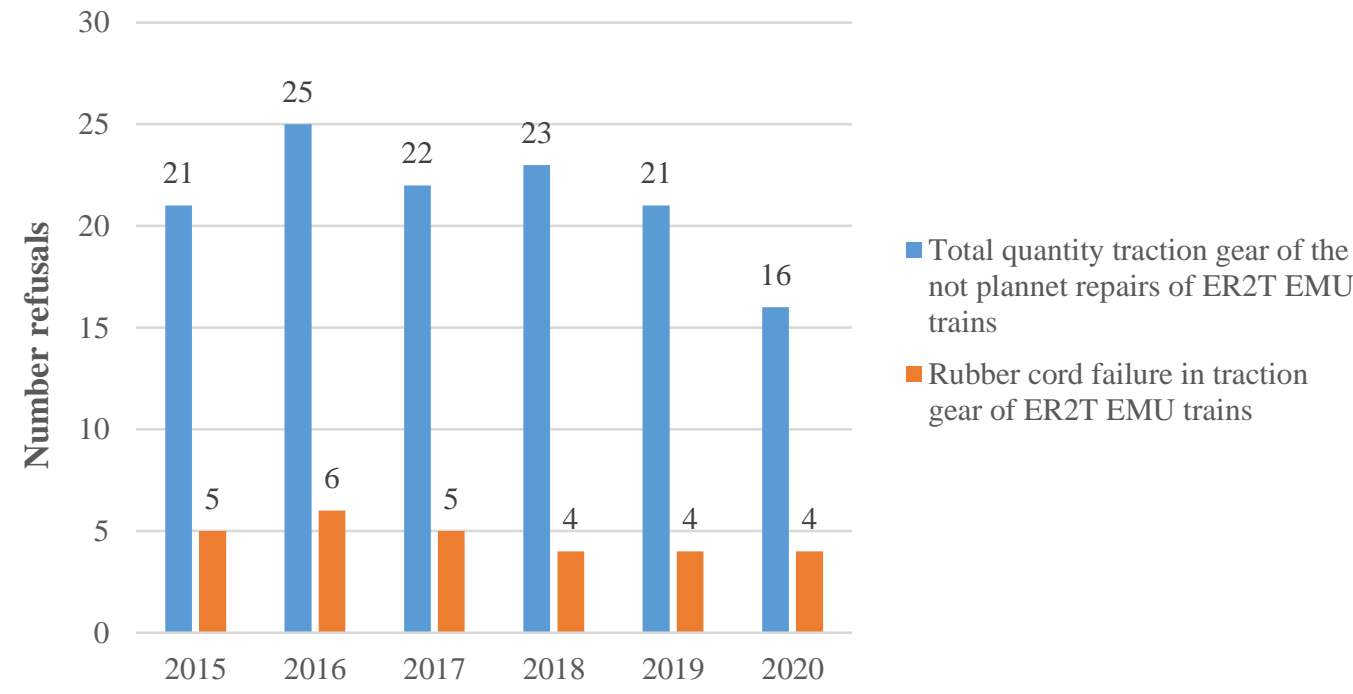

Fig. 2. Number of unscheduled repairs in traction drives and rubber-cord damage 2015-2020

The graph in Fig. 2 shows the total number of unscheduled repairs of the traction drive of the ER2T series EMU trains, in comparison with the total number of unscheduled repairs of the traction drive due to the rupture of the rubber-cord coupling shell. Failures of the rubber-cord coupling are more than $21 \%$ of the total number of traction drive failures.

It is important to reduce the number of unscheduled repairs, associated with the elimination of the rubber-cord coupling damage consequences, which are related to high labor intensity and high financial costs for replacement, as well as downtime of motor cars for unscheduled repairs, which can be up to two days. In this regard, it becomes necessary to study the appearance of the causes of rupture of the rubber-cord coupling shell. Also, additional questions arise regarding the study of the temperature effect and the effect of MOL Alugear LKP 000 gear wheel lubricant on the coupling and the compliance of the rubber-cord coupling material quality with the requirements of GOST 33188-2014 standard.

\section{Research methods}

To determine the causes of failures a rubber-cord coupling, removed from the motor car ER2T No.2207-02 after unscheduled repair due to a rupture of the side surface (Fig. 3), was taken for research.

Replacement of the cord coupling according to the repair rules L31/97 [4] should be carried out during the type TR-3 periodical repair in October 2019. The car, after being repaired in the volume of TR-3, was put into operation on October 29, 2019, but already on July 20, 2020, while performing type TA-3 maintenance, a rupture of the side shell of the rubber-cord coupling was noted.

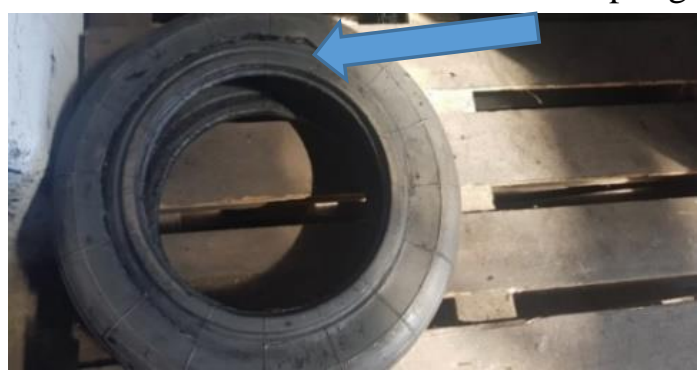

Fig. 3. ER2T 2207-02 damage to the side surface of the ER2T 2207-02 motor car rubber cord

During visual inspection, it was found that on the coupling from the side of the traction motor, at the place of torque transmission, there is a presence of grease on the side surface of the coupling. Cracks 
and ruptures of the side surface of the coupling were also found along the entire circumference not far from the place where the coupling was attached to the flange. This type of failure associated with the destruction of the shell in the circular section at the clamping of the flanges is the most common failure of the coupling, and accounts for more than $90 \%$ of the total number of failures of the of ER2T series EMU train couplings. According to the mileage reports (PVR4-template) [5] the failure of the rubbercord coupling occurred when the car reached the mileage of $97598 \mathrm{~km}$. It should be noted that when installing a new coupling, in accordance with GOST 33118-2014 requirements, the mean mileage between failures must be at least 200 thousand $\mathrm{km}$. When analysing the statistical data of the JSC "Pasažieru vilciens" motor cars mileage (PVR-4 template), on which failures of rubber-cord couplings were found, it was revealed that the mean mileage between failures of the couplings was:

- 2015 - 112.2 thousand $\mathrm{km}$;

- 2016 - 116.2 thousand $\mathrm{km}$;

- 2017 - 118.5 thousand km;

- 2018 - 124.3 thousand $\mathrm{km}$;

- 2019 - 128.03 thousand km;

- 2020 - 126.08 thousand $\mathrm{km}$.

In the period from 2015 till 2020 with a mileage of more than 200 thousand $\mathrm{km}$ at the time of the failure, only 3 failures of rubber-cord couplings out of 28 couplings were revealed (which is just over $10 \%$ of all failures). One possible reason for the failure of rubber-cord couplings in the mileage range from 112 to 126 thousand $\mathrm{km}$ is their untimely replacement with new during type TR-3 repair, and the replacement of the couplings was carried out according to their actual state instead.

To determine the temperature of the rubber-cord coupling in the real operating conditions, on 23.07.2020, a trial was carried out on a 4-car ER2T series EMU train No. 7115R on the route Riga Jelgava. The results of measurements, the temperature of the outer shell of the rubber-cord coupling are shown in Table 1.

EMU train ER2T 7115R cord coupling temperature for cars No.7114-04; No.7115-10

Table 1

\begin{tabular}{|c|c|c|c|}
\hline $\begin{array}{c}\text { Air temperature } \\
\text { at Jelgava } \\
\text { station } \mathbf{t},{ }^{\circ} \mathrm{C}\end{array}$ & $\begin{array}{c}\text { Wheels } \\
\text { No. }\end{array}$ & $\begin{array}{c}\text { Car No. } 7114-04 \\
\text { rubber-cord coupling } \\
\text { temperature } t,{ }^{\circ} \mathrm{C}\end{array}$ & $\begin{array}{c}\text { Car No.7115-10 } \\
\text { rubber-cord coupling } \\
\text { temperature } t,{ }^{\circ} \mathrm{C}\end{array}$ \\
\hline \multirow{4}{*}{$+25^{\circ} \mathrm{C}$} & 1 & +40.2 & +43.1 \\
\hline & 2 & +37.8 & +37.0 \\
\hline & 3 & +39.2 & +40.2 \\
\hline & 4 & +40.4 & +38.6 \\
\hline
\end{tabular}

According to the results of the temperature measurements and visual inspection of 8 rubber-cord couplings of an EMU train, the presence of grease and signs of temperature caused aging, as well as the presence of small cracks on the side surface was established. The mileage of the cars from the type TR3 repair at the time of the temperature measurements were:

- car ER2T 7114-04 - $200420 \mathrm{~km}$;

- car ER2T 7115-10 - $228034 \mathrm{~km}$.

It is possible that under more severe operating conditions, such as the maximum occupancy of cars and the ambient temperature more than $+30^{\circ} \mathrm{C}$, the temperature of the cord coupling can reach more than $+60^{\circ} \mathrm{C}$.

The research process of the rubber-cord coupling consisted of four stages.

1. At the first stage:

- preparation of the rubber-cord coupling material for the research;

- determination of the geometric dimensions of the coupling and comparison of the data obtained from GOST 33188-2014 standard.

2. At the second stage, the theoretical determination of the shear stress and radial load acting on the coupling. 
3. At the third stage - research in the RTU laboratory, determination of Shore hardness depending on the temperature of the rubber cord in the range from $-20^{\circ} \mathrm{C}$ to $+60^{\circ} \mathrm{C}$. And also the influence study of the gearbox lubricant "MOL Aluger LKP000" on the outer shell of the rubber-cord coupling.

4. At the fourth stage of the study - making the main conclusions about the causes of rubber-cord coupling rupture.

At the first stage, the geometric dimensions of the rubber-cord coupling were determined, the diameter of the outer surface of the coupling, the inner diameter and the thickness of the flange were determined, Fig. 4. To determine the geometric dimensions, two fragments were cut from the coupling.

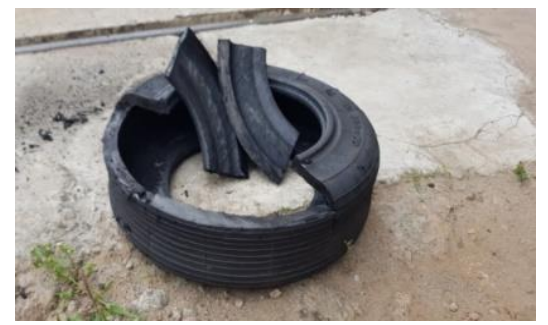

Fig. 4. Preparation of the rubber cord coupling for measurement

The measurement data are shown in Table 2.

Table 2

Determination of the geometric dimensions of the coupling

\begin{tabular}{|l|c|c|}
\hline \multirow{2}{*}{ Measurement } & \multicolumn{2}{|c|}{ Measurement value } \\
\cline { 2 - 3 } & $\begin{array}{c}\text { Test sample, } \\
\mathrm{mm}\end{array}$ & $\begin{array}{c}\text { Parameters of GOST } \\
33188-2014, \mathrm{~mm}\end{array}$ \\
\hline Diameter of the outer surface of the coupling & 524.1 & $520^{+2}$ \\
\hline Inner diameter & 319 & $319_{-2}+2$ \\
\hline Flange thickness & 28.4 & $28_{-2}+2$ \\
\hline
\end{tabular}

According to the results of the measurements it was stated that the dimensions of the investigated coupling in terms of the diameter of the outer surface and the thickness of the flange do not meet the requirements of GOST 33188-2014. The thickness of the flange was $28.4 \mathrm{~mm}$, Fig. 5.

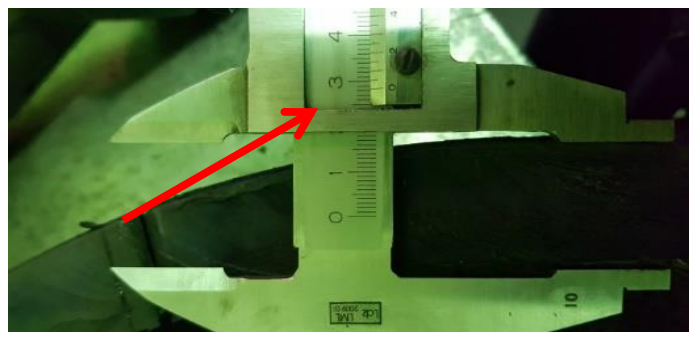

Fig. 5. Flange thickness measurement results

Also, when measuring the side surface of the coupling, it was stated that at the point of attachment of the rubber-cord coupling to the flanges, where the traction force is transmitted from the traction motor, the coupling shell has the smallest wall thickness. According to the measurement results, the side surface of the coupling has the smallest thickness, which was $19.4 \mathrm{~mm}$, Fig. 6.

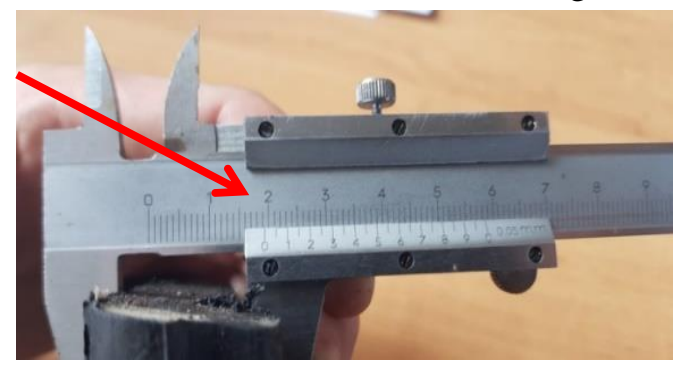

Fig. 6. Result of measuring the side surface of the coupling at the fastening place 
At the second stage, the determination of the shear stress $\tau_{s}$ and the radial load $F_{r}$ acting on the cord coupling during movement was done. The most common failure of the coupling associated with the destruction of the shell in the circular section at the clamping of the flanges arising during the transmission of torque are the acting shear stresses of the twisting shear $\tau_{s}$.

Shear strength of the shell:

$$
\begin{gathered}
\tau_{s}=\frac{2000 \cdot M_{a}}{\pi \cdot D_{1}^{2} \cdot b} \leq[\tau], \\
b=19.4 \mathrm{~mm}-\tau_{s}=0.287 \mathrm{MPa} \\
b=21.5 \mathrm{~mm}-\tau_{s}=0.260 \mathrm{MPa}
\end{gathered}
$$

where $[\tau]-$ permissible shear stresses of the shear in the shell $=0.45-0.50 \mathrm{MPa}[6]$;

$b$ - shell thickness together with shear $=19.4 \mathrm{~mm}$;

$D_{1}$ - diameter of the coupling at the point where the coupling is attached to the flange $=0.45 \mathrm{~m}$.

$M_{a}-$ torque on the rotor shaft, $\mathrm{N} \cdot \mathrm{m}$.

$$
M_{a}=0.159 \cdot \frac{P \cdot \eta}{n}=1777.5 \mathrm{~N} \cdot \mathrm{m}
$$

where $P$-traction motor power $=258.75 \mathrm{~kW}$;

$n-$ traction motor speed $=20.83$ rotation $\cdot \mathrm{s}^{-1}$;

$\eta$ - efficiency of the traction motor $=90 \%$.

With the frame supported suspension of the traction motor, part of the traction motor weight rests on the rubber-cord coupling, as a result of which the gravity force of the engine acts on the coupling at the attachment point which stretches it [7]. When a large number of passengers are transported in a carriage (during morning and evening rush hours, as well as in the summer season), the shaft of the traction motor is displaced in relation to the shaft of the small gear of the gearbox. The coupling compensates this misalignment of the shafts and, as a result, an additional radial load $F_{r}$ arises in the coupling material.

$$
F_{r}=(0.1 \ldots 0.3) \cdot F_{r}^{\prime}=0.2 \cdot 6.83 \cdot 10^{6}=1.36 \cdot 10^{6} \mathrm{~N}
$$

where $F_{r}{ }^{\prime}$ - circumferential force on the coupling shell, N.

$$
F_{r}^{\prime}=\frac{2000 \cdot M_{a}}{D}=6.83 \cdot 10^{6} \mathrm{~N}
$$

where $D$ - coupling diameter $=0.52 \mathrm{~m}$.

According to the calculations results to determine the radial load acting on the rubber-cord coupling it was found that with a large misalignment of the shafts, the rubber-cord coupling is subject to a large value of the radial load, as well as when the torque is transmitted - in the place of the coupling fastening to the flanges, it experiences shear stresses of the twist.

Determination of the effect of "MOL Alugear LKP 000" lubricant and temperature on the hardness of the rubber-cord coupling material.During the operation of the traction gear of the ER2T series EMU trains, as a result of the labyrinth rings surface wear, the gear wheels lubricant MOL Alugear LKP 000 is ejected and, as a result, a part of the lubricant falls on the outer side surface of the coupling, Fig. 7.

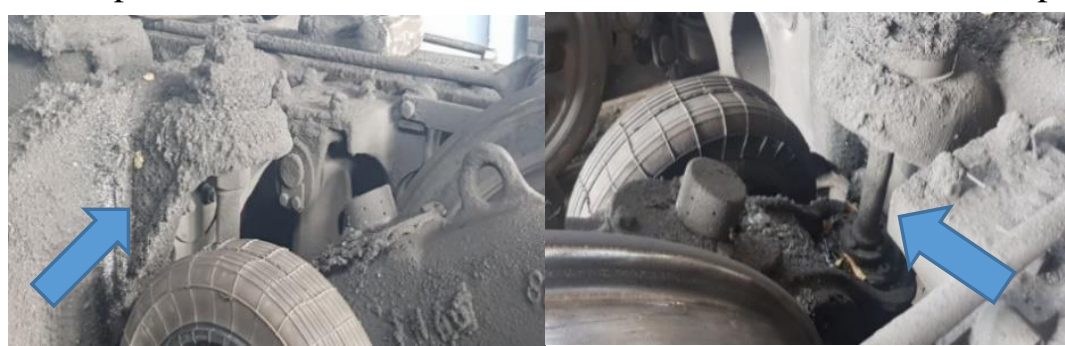

Fig. 7. Leakage of grease from the gear unit on the car ER2T 7117-08 
To study the effect of MOL Alugear LKP 000 lubricant, tests were carried out to determine the hardness of rubber-cord couplings sample 1 and sample 2 (Fig. 8) in the chemical laboratory of the RTU. Also, studies have been carried out on the temperature effect on the shell of the rubber-cord coupling [8].

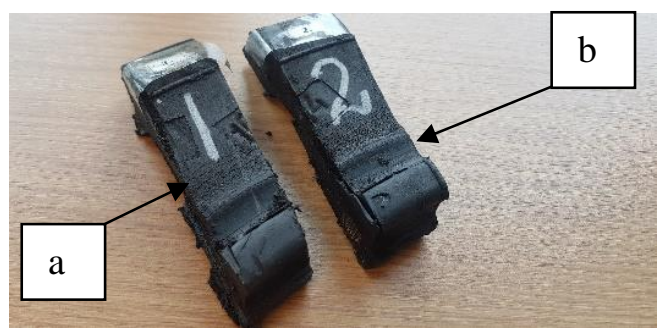

Fig. 8. Samples for determining the influence of temperature and the action of the lubricant: $\mathrm{a}$ - Sample 1, b-Sample 2

The data obtained were compared with the GOST 33188-2014 standard requirements. The test data are given in Table 3 [9].

\section{Revealing the effect of lubrication and temperature on the hardness of rubber-cord coupling specimens}

\begin{tabular}{|c|c|c|c|c|}
\hline \multirow[b]{2}{*}{$\begin{array}{l}\text { Shore A hardness for rubber, } \\
\text { conventional units }\end{array}$} & \multicolumn{4}{|c|}{ Measurements } \\
\hline & $\begin{array}{l}\mathrm{t}=+23^{\circ} \mathrm{C} \\
\text { (average) }\end{array}$ & $\begin{array}{l}\mathrm{t}=+60^{\circ} \mathrm{C} \\
\text { (average) }\end{array}$ & $\begin{array}{l}\mathrm{t}=-20^{\circ} \mathrm{C} \\
\text { (average) }\end{array}$ & $\begin{array}{c}\text { GOST } \\
\text { 33188-2014 }\end{array}$ \\
\hline Sample 1 top & 65 & 60 & - & $50.0-65.0$ \\
\hline Sample 1 middle part & 52.7 & 52.42 & - & $50.0-65.0$ \\
\hline Sample 1 lower part & 66.5 & 66.5 & - & $50.0-65.0$ \\
\hline Sample 2 top & 61 & - & 66 & $50.0-65.0$ \\
\hline Sample 2 middle part & 56 & - & 62 & $50.0-65.0$ \\
\hline Sample 2 lower part & 66 & - & 71.5 & $50.0-65.0$ \\
\hline Samp 3 MOL Alugear LKP 000 middle part & 49 & 45 & 52 & $50.0-65.0$ \\
\hline
\end{tabular}

\section{Conclusions}

1. The first possible reason for failure of the coupling, when reaching the mileage of 97 thousand $\mathrm{km}$, is not timely replacement with a new one during type TR-3 repair, and the coupling was replaced on the basis of its actual condition instead.

2. As a result of the measurements, it was found that the diameter of the outer surface of the coupling $2.1 \mathrm{~mm}$ did not correspond to the requirements of GOST 30188-2014 standard. Since the failure of the coupling occurred in the summer season, when there is a large load of cars by passengers, the second possible reason for the failure was the appearance of an additional radial load in the material of the rubber-cord coupling. According to the results of calculations to determine the radial load acting on the rubber-cord coupling it was found out that a large value of the radial load $\mathrm{F}_{\mathrm{r}}$ leads to stretching of the lateral surface, an increase in the size of the coupling and, accordingly, to rupture of the rubber-cord coupling.

3. When carrying out calculations to determine the shear stress $\tau_{s}$, it was found that with an increase in the thickness of the coupling shell from $19.4 \mathrm{~mm}$ to $21.5 \mathrm{~mm}$, the contact stress at the point of attachment of the coupling decreases from $2.882 \cdot 10^{5}$ to $2.6 \cdot 10^{5}$ (by $0.26 \mathrm{MPa}$ ). To prevent rupture of the coupling shell at the attachment point, it is necessary to consider measures to increase the thickness of the side surface of the coupling by $10 \%$ at the point of attachment to the flanges of the traction motor and the small gear.

4. The third possible reason for the failure of the coupling is the overestimated hardness according to the Shore method at all studied temperatures in the lower part of the samples (that is, in the place where the coupling is attached to the flange). For 1 specimen, the lower part, the discrepancy by 
1.5 con. units at temperatures $\mathrm{t}+23^{\circ} \mathrm{C}$ and $\mathrm{t}+60^{\circ} \mathrm{C}$, the hardness was 66.5 con. units. 2 samples - the lower part, not corresponding to 1 unit, the hardness was 66 con. units, at a temperature of $+23{ }^{\circ} \mathrm{C}$ and $6.5 \mathrm{con}$. units, at a temperature of $-20^{\circ} \mathrm{C}$ and amounted to $71.5 \mathrm{con}$. units.

5. The fourth reason for the failure of the coupling is the possible effect of lubricant on the outer surface of the coupling shell, as a result of which there is a partial absorption of lubricant by the outer cover layer of the coupling - "swelling". The increase in the volume of the coupling was ascertained from the results of measurements of the flange thickness, which was $28.4 \mathrm{~mm}$, which by $0.2 \mathrm{~mm}$ does not meet the requirements of GOST 30188-2014 standard. Also, according to the results of measuring the hardness by the Shore method, for a sample treated with MOL Alugear LKP 000 lubricant at a temperature of $+60{ }^{\circ} \mathrm{C}$, it was found that the hardness did not meet the requirements of GOST 30188-2014 standard by 5 con. units, the hardness was 45 con. units.

\section{References}

[1] Цукало П.В., Просвирин Б.К., Эксплуатация электропоездов: Справочник - Москва: Транспорт, 1994. 383стр. Cukalo P.V., Prosvirin B.K. Operation of electric trains: Manual Moscow: Transport, 1994. 383 p. (In Russian).

[2] Пегов Д.В., Бурцев П.В., Андреев В.Е., Электропоезда постоянного тока ЭТ2, ЭТ2М, ЭР2Т, ЭД2Т Москва: Транспорт, 2003 (DC electric trains ЭТ2, ЭТ2М, ЭР2Т, ЭД2Т) Moscow: Transport, 2003. 184 p. (In Russian).

[3] Elektrovilcienu neplāna remontu kopsavilkums AS "Pasažieru vilciens" (forma FT-22) (Summary of non-scheduled repairs of electric trains AS "Pasažieru vilciens" (template FT-22)) (In Latvian).

[4] Elektrovilcienu tekošā remontu un tehniskas apkalpošanas noteikumi L31/97 Valsts akciju sabiedrība "Latvijas dzelzcel̦ šs" Rīga 1997g. 152 lpp. Electric train periodical repair and technical servicing regulations L31/97 State stock company "Latvijas dzelzcel̦š" Riga 1997g. 152 p. (In Latvian).

[5] Elektrovilcienu nobraukumu atskaite AS "Pasažieru vilciens" (forma PVR-4) (Mileage reports of electric trains AS "Pasažieru vilciens" (template PVR-4)) (In Latvian).

[6] Муфты тягового привода моторвагонного подвижного состава. Резино кордовые оболочки ГОCT 30188-2014. Traction gear couplings electric multiple unit (EMU) trains. Rubber cord casings. GOST 30188-2014. (In Russian).

[7] Korneev, V.S., Romanyuk, D.A., Korneev, S.A., Russkih, G.S., Vaskova, M.V. Finite Element Research of Rubber-cord Flat Coupling (2016) Procedia Engineering, 152, pp. 321-326.

[8] M. Levinson I.W. Burgess. A comparison of some simple constitutive relations for slightly compressible rubber-like materials// Int. J. Mech. Sci. - Vol. 13., 1971, pp. 563-572.

[9] Majeed, B., Basturk, S. Analysis of polymeric composite materials for frictional wear resistance purposes, Polymers and Polymer Composites, 29 (2), 2021, pp. 127-137. 